\title{
MENANGKAL KRITIKUS ALKITAB BAHWA MANUSIA BUKAN CIPTAAN TUHAN YANG SEMPURNA DAN TIDAK LEBIH BAIK DARI BINATANG
}

\author{
oleh \\ ${ }^{* 1}$ Hery Harjanto dan ${ }^{* 2}$ Hery Fitriyanto \\ ${ }^{* 1}$ Dosen Tetap STT Gamaliel \\ ${ }^{*}$ Mahasiswa STT Gamaliel \\ Email: ${ }^{* 1}$ heryharjanto23@gmail.com, ${ }^{* 2}$ fitriyanto.hery@gmail.com
}

\begin{abstract}
ABSTRAK - Kemajuan ilmu pengetahuan dan teknologi telah menghasilkan pemikir-pemikir yang kritis dalam berbagai bidang, termasuk kritik terhadap Alkitab. Para kritikus mengatakan yaitu bahwa manusia bukan ciptaan Allah yang sempurna dan tidak lebih baik dari binatang. Tulisan ini bertujuan untuk memberikan jawaban alkitabiah terhadap isu ini dan menunjukan ketaksalahan Alkitab. Penelitian ini menggunakan pendekatan kualitatif deskriptif dengan metode hermeneutika dan studi literatur. Adapun hasil dari penelitian adalah bahwa manusia adalah ciptaan Allah, diciptakan segambar dan serupa Allah dan sempurna adanya. Manusia menjadi jahat bahkan kejahatannya melebihi binatang terjadi setelah manusia yang sempurna itu jatuh ke dalam dosa.
\end{abstract}

Kata kunci : Allah, Penciptaan Manusia, Sempurna, Ketaksalahan Alkitab

ABSTRACT - Science and tecnology advancement produce some philosophers that criticize all things, including the Bible. Those philosophers said that human beings are not the creation of God that is perfect and better than animal. This article aims to give a biblical answer to this issue dan prove inerransy of The Bible. This reseach use qualitative descriptive approach with hermeneutic and literature study method. This research found that human beings are the creation of God that is created in the image and likeness of God and perfect. Human beings become evil more than animal after fell into sin.

Keyword: God, The Creation Of Human Being, Perfect, Inerrancy of The Bible

\section{PENDAHULUAN}

Ronald H. Nash menyebutkan dua elemen paling penting wawasan dunia (world view) tentang perkara keallahan, yaitu teisme dan ateisme. Ia menulis, baik teisme maupun ateisme akan selalu termasuk dalam suatu wawasan dunia. Bagian terpenting dari wawasan dunia adalah apa yang dikatakannya tentang Allah dan apa yang tidak dikatakannya 
tentang Allah. Satu komponen hakiki dari wawasan dunia adalah pandangannya tentang Allah. Dua kategori wawasan dunia ini sebagai dua kelompok yang sedang saling bersaing untuk merebut dan mendapatkan para penganut. Sering kali persaingan antar dua kategori wawasan ini menimbulkan konflik. ${ }^{1}$

Pada umumnya kritikus Alkitab dalam hal ini kaum ateis berpendapat bahwa Allah dalam Alkitab tidaklah mungkin mahakuasa dan mahasempurna. Pendapat tersebut kemudian dikaitkan dengan manusia yang mereka pertanyakan sebagai ciptaan Allah yang sempurna. Karena secara logika, ketidaksempurnaan pasti tidak akan bisa mencipatakan sesuatu yang sempurna. Kaum Ateis mendukung pandangan Darwin dengan teori evolusinya bahwa tidak perbedaan anatara manusia dengan monyet oleh karena keduanya memiliki asal usul nenek moyang yang sama dan satu. Lebih lanjut Darwin berpandangan bahwa ketidak-samaan antara manusia terjadi pada tataran derajat tetapi tidak terjadi dalam jenis. Manusia mampu melakukan olah pikir dengan akal budinya oleh karena proses evolusi dari kondisi tidak mampu berpikir, kemudian secara perlahan-lahan manusia berkembang menjadi sosok yang mampu

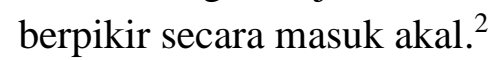

Penganut Ateis memiliki penjelasan tentang cara terciptanya alam semesta termasuk manusia. Dunia dan segala isinya terjadi melalui aksi dan reaksi aneka ragam unsur kimia dengan

\footnotetext{
${ }^{1}$ Iswara Rintis Purwantara, Prapenginjilan, Menyingkirkan Kendala-Kendala Intelektual Dalam Penginjilan (Yogyakarta: Penerbit Andi, 2012), 214.

${ }^{2}$ Fritz Ridenour, Dapatkah Alkitab Dipercaya? (Jakarta: PT. BPK Gunung Mulia, 1993), 153.
}

kekhasannya masing-masing seperti zat besi, oksigen dan lainnya serta zat inteligensia dan masih banyak unsur lain yang belum dikenali identitasnya. Aksi dan reaksi kimiawi itu menghasilkan makhluk satu sel yang masih sederhana. Adapun makhluk ini tidak statis tetapi kemudian berkembang ketingkat yang lebih tinggi menjadi makhluk berkaki, dan aneka makhluk hidup di habitat air, udara dan lainnya. Hasil reaksi unsur kimiawi ini juga menjadi pangkal berkembangnya aneka pepohonan dan proses kehidupannya. Demkian pula melalui proses evolusi terbentuk manusia purba, manusia primitif dan manusia modern sebagaimana saat ini. Proses berlangsungnya evolusi dari semua makhluk hidup diatur oleh kerja zat intelegensia. Refleksi kerja tampak dari kemampuan manusia melakukan aneka rekayasa kehidupan dan juga rekayasa genetika sehingga menjadi sesuatu yang lebih baik.

Kaum ateis walaupun tidak percaya adanya Tuhan sebagai pencipta alam semesta dan manusia, namun memberikan kritik terhadap aneka karya ciptaan Tuhan. Salah satu isunya adalah menolak manusia sebagai hasil kastua ciptaan Allah yang sempurna serta menolak bahwa manusia adalah makhluk yang lebih baik dari binatang. Minimal ada dua bukti yang ajukan bertolak dari kenyataan sehari-hari yaitu pertama, perbandingan indra manusia dengan indra binatang; kedua, perbuatan manusia yang lebih kejam dibanding perilaku binatang.

\section{Perbandingan indra manusia dengan indra binatang}

Kaum Ateis membandingkan beberapa indra yang dimiliki manusia pada 
umumnya dan ternyata tidak lebih baik bahkan kalah jauh bila dibandingkan dengan indra binatang. Indra tersebut adalah sebagai berikut :

\section{Indra penglihatan/mata}

Menurut penelitian, mata manusia dapat menyelesaikan sekitar 60 siklus per derajat. Di sisi lain beberapa burung pemangsa dapat melihat sebanyak 140 siklus per derajat. Hal ini memungkinkan elang dan predator lainnya untuk memilih mangsa dari ribuan kaki di atas udara.

\section{Indra pendengaran/telinga}

Ada perbedaan antara manusia dan burung terkait dengan pendengaran. Manusia menerima suara lewat pitch yang relatif jauh lebih rendah dibandingkan dengan burung yang mampu mengidentifikasi dan mengingat pitch (kunci) suara mutlak. Burung mampu mendengar not suara yang lebih pendek daripada manusia. Burung juga mampu membedakan suara hingga mencapai 1/200 per detik sedangkan hanya sekitar $1 / 20$ per detik. $^{3}$

Baru-baru ini, peneliti dari University of Strathclyde, Glasgow menemukan bahwa ngengat lilin raksasa (Galleria mellonella) memiliki pendengaran ekstrem karena bisa mendengar suara hingga 300 ribu $\mathrm{Hz}$. Manusia sendiri hanya bisa mendengar rentang suara 20-20 ribu Hz. ${ }^{4}$ Anjing

\footnotetext{
${ }^{3}$ Husein Avicenna Akil, "Sepuluh Kali Lebih Sensitif Ketimbang Manusia," Lembaga Ilmu Pengetahuan Indonesia, last modified 2010, accessed March 25, 2021, http://lipi.go.id/berita/sepuluh-kali-lebihsensitifketimbang-manusia/5648.

${ }^{4}$ Yudha and Bayu D. Wicaksono, "7 Hewan

Dengan Pendengaran Terbaik Di Dunia, Kelelawar
}

mampu mendengar frekuensi suara dari 250 Hertz hingga 50.000 Hertz. Sementara telinga manusia hanya bisa mendengar maksimal $20.000 \mathrm{~Hz}^{5}$

\section{Indra penciuman/hidung}

Hidung beruang memiliki ribuan reseptor bau sehingga mampu berbagai hal bahkan mampu mendeteksi hewan mati pada jarak 32 kilometer. Hal mana tidak dimiliki oleh manusia. Bahkan penciumannya 2.100 kali lebih baik daripada penciuman manusia. Demikian pula anjing pelacak memiliki indera penciuman 300 kali lebih baik daripada manusia karena memiliki 230-an juta sel penciuman. Bahkan ia memiliki reseptor bau 40 kali lebih banyak daripada manusia serta mampu melacak bau tertentu yang berjarak lebih dari $200 \mathrm{~km}{ }^{6}$

\section{Perbuatan manusia yang lebih kejam dibanding perilaku binatang}

Kritik kaum ateis berikutnya yaitu mempertanyakan, bila manusia adalah ciptaan yang sempurna dan lebih baik dari binatang, mengapa manusia bisa melakukan perbuatan-perbuatan yang kejam

Bukan Juaranya!," IDN Times, last modified 2019, accessed March 25, 2021,

https://www.idntimes.com/science/discovery/viktor -yudha/hewan-dengan-pendengaran-terbaik/7.

5 "Mengapa Pendengaran Anjing Lebih Peka Dibanding Manusia?," DW.Com, last modified 2018, accessed March 25, 2021,

https://www.dw.com/id/mengapa-pendengarananjing-lebih-peka-dibanding-manusia/av45102248\#: :text=Iptek-,Mengapa Pendengaran Anjing Lebih Peka Dibanding Manusia\%3F,dan jadi tidak bisa tenang.

${ }^{6}$ Rizka Diputra, "Lima Hewan Dengan Indera Penciuman Terbaik Di Dunia," Okezone.Com, last modified 2016, accessed March 25, 2021, https://techno.okezone.com/read/2016/03/24/56/13 44743/lima-hewan-dengan-indera-penciumanterbaik-di-dunia. 
yang bahkan binatang tidak melakukannya. Sebagai contoh kisah ibu yang tega membuang atau bahkan membunuh bayinya sendiri dengan alasan apapun. Apabila dibandingkan dengan binatang bahkan seekor harimaupun sebagai binatang paling buas, ternyata tidak akan memangsa anaknya sendiri. Manusia dikaruniai akal dan merupakan merupakan makhluk yang bermoral dimana hal moral itu adalah sesuatu yang tidak dimiliki binatang, tetapi mengapa ada manusia yang moralnya lebih bejat dibanding binatang?

Pandangan kaum Ateis ini dapat mengakibatkan orang percaya menjadi ragu-ragu tentang keyakinannya berdasarkan Firman Allah. Bahkan membuat orang percaya meninggalkan imannya dan menjadi pengikut Ateisme. Padahal tanggungjawab orang percaya sesungguhnya adalah juga untuk menjangkau kaum Ateis untuk mempercayai Firman Allah. Oleh karena itu penulis tertarik untuk melakukan penelitian dalam rangka merumuskan jawaban alkitabiah kepada kaum Atesis.

\section{RUMUSAN MASALAH}

Berdasarkan uraian di bagian pendahuluan maka rumusan masalah pada penelitian ini adalah bagaimana jawaban alkitabiah terhadap pandangan kaum Ateis yang mengatakan bahwa manusia bukan ciptaan Tuhan yang sempurna dan tidak lebih baik dari binatang?

Tujuan penelitian ini adalah memberikan jawaban alkitabiah terhadap terhadap kritik kaum Ateis yang mengatakan bahwa manusia tidak sempurna dan tidak lebih baik dari binatang. Sekaligus jawaban alkitabiah akan mengoreksi kaum Ateis bahwa hanya dengan membandingkan beberapa indra manusia dengan indra yang dimiliki binatang dan kekejaman orang yang melebihi binatang lalu menyimpulkan bahwa manusia ciptaan Tuhan yang tidak lebih baik dari pada binatang adalah kesimpulan yang tidak tepat.

Manfaat dari penelitian ini adalah menguatkan iman orang percaya agar tetap kokoh dalam iman berdasarkan Firman Allah. Penelitian ini juga memampukan orang percaya untuk memberi pertanggung jawaban imannya kaum Ateis.

\section{METODE PENELITIAN}

Penelitian ini menggunakan pendekatan kualitatif deskriptif. 7 Metode pengumpulan data yaitu hermeneutika alkitabiah terhadap teks-teks Alkitab dan studi pustaka yang terkait dengan masalah yang dibahas. ${ }^{8}$ Data yang akan dicari adalah kondisi manusia ketika diciptakan dan ketika manusia telah jatuh dalam dosa.

\section{HASIL DAN PEMBAHASAN}

\section{Manusia Pada Mulanya}

Penciptaan manusia dilakukan secara berbeda dan istimewa dibandingkan dengan ciptaan yang lain. Ketika Allah menciptakan selain manusia diawali

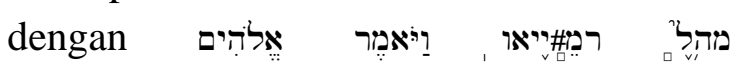
(berfirmanlah Allah) dan disusul dengan kata יהיה:-jadilah) (Kej 1:3,6,9,11,14,20,24). Allah menciptakan

\footnotetext{
${ }^{7}$ Stevri Indra Danik Astuti Lumintang Lumintang, Theologia Penelitian Dan Penelitian Theologis Science-Ascience Serta Metodologinya (Jakarta: Geneva Insani Indonesia, 2016), 99.

8 J. Lexy Moleong, Metode Penelitian Kualitatif (Bandung: PN Remaja Rosdakarya, 1997), 113.
} 
segala sesuatu dari dari kondisi tidak ada lalu menjadi ada. Berturut-turut di dalam peristiwa penciptaan: Jadilah terang, jadilah cakrawala, jadilah air yang dibawah matahari berkumpul pada satu tempat (daratan), jadilah tumbuhan, jadilah bendabenda penerang pada cakrawala, jadilah makhluk hidup, ternak dan binatang. Sedangkan ketika Allah menciptakan manusia dalam Kejadian 1:26 Ia berkata

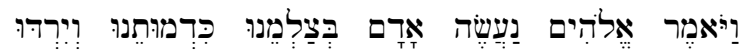
אים - Then God said, "Let us make man in our image,in our likeness ...). Kata עשה ,עשֶׁה (verb qal imperfect 1st person common plural cohortative in meaning) berarti membuat (make). Jadi manusia (adam) adalah dibuat Allah atau karya Allah. Tuhan Allah membuat manusia itu dari debu tanah. Selajutnya Tuhan menghembuskan nafas hidup ke dalam hidungnya. Oleh karena nafas ini, manusia menjadi mahkluk yang hidup (Kej. 7:7).

Allah menciptakan manusia melalui dua tahap. Pertama Allah membuat bentuk manusia dari debu tanah. Kedua Allah menghembuskan nafas-Nya sendiri ke dalam lubang hidung manusia. Jadi proses ini yang membedakan penciptaan manusia dan ciptaan yang lain. Dari awal penciptaan Allah sendiri yang membentuk manusia bukan kekuatan lain. Manusia bukan evolusi dari kera seperti teorinya Darwin. Manusia yang dibuat dari debu tanah tidak bernyawa sampai Allah menghembuskan nafas-Nya sendiri baru manusia hidup. Jadi Allah dan kuasa-Nya adalah sumber kehidupan manusia. Manusia menjadi ciptaan yang istimewa dari segala ciptaan yang ada.

Kejadian 1-2 menceritakan bahwa manusia diciptakan Allah secara langsung
(Kej. 1:27; 2:7; 5:1; Ul. 4:32. ${ }^{9}$ Menurut Kejadian 1:26, manusia diciptakan menurut gambar dan rupa Allah (bhs. Ibrani: tselem demuth). Tselem menunjuk pada gambar, artinya bahwa manusia komponen-komponen yang terdapat juga dalam Allah. Contoh dari komponenkomponen ini adalah pikiran, perasaan, dan kehendak. Demuth berarti keserupaan, kemiripan. Dengan kata lain, demuth menunjuk pada kualitas. Menurut gambar dan rupa Allah dalam bahasa Latin diterjemahkan imago dan similitudo. ${ }^{10}$

Manusia merupakan puncak atau maha karya dari karya penciptaan Allah. Manusia memiliki komponen yang tidak dimiliki oleh ciptaan lain. Bahkan dikatakan bahwa manusia adalah gambar dan rupa Allah karena kepada manusia diberikan komponen yang sama dengan Allah. Frasa segambar dan serupa Allah mengindikasikan manusia memiliki kemiripan eksistensi dan keterampilan seperti Allah. ${ }^{11}$

Manusia adalah mahkluk yang kudus seperti Allah yang kudus. Kekudusan manusia terlihat ketika di taman Eden dan mereka telanjang tetapi tidak merasa malu (Kejadian 2:25). Bukti kekudusan manusia juga terlihat dari relasinya dengan Allah. Manusia bebas

\footnotetext{
${ }^{9}$ Paul Enns, The Moody Handbook of Theology (Chicago: Moody Press, 1989), 303.

${ }^{10}$ Soleman Kawangmani and Irawan Budi Lukmono, "Efektivitas Pembelajaran Agama Kristen Melalui Mata Kuliah Pendidikan Agama Kristen Di Perguruan Tinggi Terhadap Pemahaman Mahasiswa Kristen Tentang Gambar Diri," Jurnal Gamaliel : Teologi Praktika 2, no. 1 (2020): 1-10. 11 "Ciptaan Yang Luar Biasa," Rehobot Ministry, last modified 2018, accessed March 26, 2021, https://www.rehobot.org/beranda_renungan/ciptaan -yang-luar-biasa/.
} 
berelasi dan bertemu dengan Tuhan yang kudus secara langsung.

Manusia adalah mahkluk yang kreatif. Kreatifitas manusia mirip dengan kreatifitas Allah. Allah sanggup menciptakan hewan dan manusia sanggup memberi nama semua hewan (Kejadian 2 : 19). Peristiwa ini membuktikan manusia memiliki kemampuan yang mirip dengan Allah.

Kemiripan dan keserupaan ini bukan berarti manusia sama dengan Allah. Allah tentu lebih unggul dibanding manusia. Allah merupakan pribadi yang lebih unggul karena Allah yang menciptakan semuanya. Kualitas karya Allahpun lebih tinggi dari manusia. Meskipun manusia lebih kecil dari Allah, namun Allah mempercayakan pengelolaan bumi dan segala ciptaan. Hal ini mengindikasikan adanya keunggulan manusia dibanding ciptaan lain.

Diciptakan menurut gambar dan rupa Allah juga berarti bahwa dalam dirinya manusia itu melekat suatu tujuan ilahi yaitu menjadi pengurus dan pengelola semua ciptaan Allah (Kejadian 1:28-31). Dan untuk melaksanakan tugas untuk menguasai bumi, maka Allah sang Pencipta memperlengkapi manusia ciptaan-Nya itu dengan kepribadian dimana tercakup di dalamnya akal, emosi, kehendak dan tekad. Perlengkapan ini tidak dimiliki oleh binatang manapun di dunia ini. ${ }^{12}$

Manusia adalah puncak seluruh ciptaan, sejenis makhluk khusus yang dihembusi napas Allah (Kejadian pasal 1). Manusia merupakan pusat rencana Allah, ditempatkan dalam suatu lingkungan

\footnotetext{
${ }^{12}$ Ridenour, Dapatkah Alkitab Dipercaya?, 164166.
}

khusus. Unsur paling istimewa dalam lingkungan Adam (manusia pertama) adalah seorang wanita bernama Hawa. Kita dapat melihat beberapa hal penting dari lingkungan istimewa itu yang dinamai "Taman Eden". Keistimewaan itu diantaranya adalah tidaklah baik bila manusia membujang (Kejadian 2:18). Maka diciptakan bagi Adam seorang kawan yang sepadan, yaitu Hawa yang juga unik. Bahkan sebelum Hawa dibentuk, semua jenis binatang dipawaikan dihadapan Adam (ayat 19, 20). Hal itu perlu supaya Adam menyadari bahwa tidak seekorpun dari binatang betina itu cocok sebagai istrinya. Adam dan Hawa adalah sederajat, walaupun jabatannya berbeda (Kejadian 1:27). Seringkali orang kafir (kafir: tidak alkitabiah) menganggap manusia sebagai salah satu jenis kehidupan sekalipun memiliki kedudukan tertinggi, sama kodratnya dengan binatang ataupun tumbuhan. Misalnya, dalam dongeng Roma yang manusia berkomunikasi dengan binatang untuk mengadakan aksi bersama. Manusia itu mencari tempat yang layak dalam susunan alam, bukannya untuk menguasai alam semesta seperti tugas manusia menurut Kejadian $1 .^{13}$

\section{Kejatuhan Manusia.}

Allah memberikan perintah sekaligus peraturan, setelah menciptakan manusia dan menempatkan mereka di dalam Taman Eden. Perintah dan peraturan tersebut yaitu manusia dapat memakan semua buah hasil dari semua pohon yang ada di Taman Eden, kecuali dari satu pohon yaitu pohon pengetahuan tentang yang baik dan yang jahat (Kejadian 2:16-

\footnotetext{
${ }^{13}$ W. Stanley Heath, Tafsir Kitab Kejadian (Yogyakarta: Yayasan Andi, 1998), 48-49.
} 
17). Apabila manusia memakan buah dari pohon tersebut maka manusia akan mati.

Manusia bukan robot yang bergerak mengikuti program pembuatnya. Manusia sebagai ciptaan Allah, diberi kehendak bebas oleh sang Pencipta. Kehendak bebas manusia berhubungan erat dengan moral dan pilihan. Manusia memperoleh kebebasan untuk membuat pilihan terkait dengan hal benar atau salah, hal yang baik dan jahat, dan termasuk memilih aneka buah dari pohon yang baik atau memilih buah dari pohon pengetahuan yang jahat. Setiap pilihan membawa tanggung jawab dan kosekuensi masingmasing.

Firman Allah mengatakan bahwa apabila manusia memakan buah pohon pengetahuan tentang yang baik dan yang jahat konsekuensinya pastilah mati. Faktanya itulah yang dipilih Hawa dan Adam. Mereka makan buah tersebut dan akhirnya keduanya mati. Nafas hidup yang diberikan oleh Allah yang menjadikan mereka hidup dihadapan Allah itu ditarik kembali. Manusia berdosa ini akhirnya kehilangan relasi dengan sumber hidup yaitu Allah. Keserupaan dengan Allah dalam diri manusia mengalami kerusakan pada saat itu. Dampaknya semua manusia keturunan Adam tidak memiliki keserupaan dengan Allah melainkan dengan Adam, manusia yang sudah jatuh dosa dan mati rohani. Sebagaimana dinyatakan dalam Kejadian 5:3, "Setelah Adam hidup seratus tiga puluh tahun, ia memperanakkan seorang laki-laki menurut rupa dan gambarnya (Adam yang sudah jatuh dosa), lalu memberi nama Set kepadanya.

\section{Dampak dari kejatuhan manusia}

Akibat kejatuhan manusia pertama dalam dosa terjadi kerusakan total pada natur manusia. Dosa ini juga menjalar kepada semua umat manusia di dunia. Seluruh manusia keturunan Adam dan Hawa memiliki natur yang rusak akibat tersentuh dosa. Dosa mencemari seluruh tubuh dan jiwa manusia. Manusia yang sudah mengalami kerusakan total ini terhilang dari persekutuan dengan Allah. Kebenaran hakiki dalam diri manusia sebagai ciptaan yang segambar dan serupa Allah juga hilang. Dengan kata lain manusia mengalami kematian rohani. Namun bukan saja kematian rohani karena kejatuhan dosa juga berakibat pada kematian jasmani seperti dijelaskan dalam kejadian 3:19 dimana manusia harus kembali menjadi debu. ${ }^{14}$

Dosa membawa manusia kepada total depravity. Total depravity atau kerusakan total merupakan kondisi dimana seluruh bagian manusia telah rusak karena pengaruh dosa. Tidak ada satu bagianpun dari manusia yang tidak terpengaruh dosa. Pikiran, perasaan, kehendak bahkan tubuh jasmani manusia telah rusak. ${ }^{15}$

Kerusakan Total tidak sama dengan kerusakan mutlak. Kerusakkan mutlak berarti bahwa manusia telah rusak dengan tingkat kerusakkan sangat parah setiap saat. Kerusakan total memang mencakup seluruh manusia. Tetapi kerusakan total cenderung menganggap bahwa apapun yang dilakukan oleh manusia tidak ada yang baik. Kejahatan ada dalam seluruh

\footnotetext{
${ }^{14}$ Louis Berkhof, Teologi Sistematika 2 (Jakarta: Lembaga Reformed Injili Indonesia, 1994), 95-96.

${ }^{15}$ David Eko Setiawan, "Dampak Injil Bagi Transformasi Spiritual Dan Sosial," BIA : Jurnal Teologi dan Pendidikan Kristen Kontekstual 2, no. 1 (2019): 87.
} 
bagian manusia. 16 Oleh karena itu, manusia tidak memiliki kemampuan untuk berbuat hal yang baik dan tidak mengingininya.

Kerusakan Total bukan menjadi bukti bahwa Kebajikan Relatif telah hilang. Manusia yang telah jatuh masih dapa melakukan kebajikan. Manusia masih dapat berbelaskasihan kepada sesama. Manusia masih memiliki kerinduan untuk mencari Tuhan. Hanya saja kebajikan yang dilakukan manusia ini bukanlah perbuatan baik yang seturut kehendak Tuhan. ${ }^{17}$

Matius 7:16-18 memberikan pernyataan bahwa manusia tidak dapat melakukan yang baik. Pada teks ini, Yesus memberikan perumpamaan bahwa hanya pohon yang baik yang akan menghasilkan buah yang baik. Demikian pula pohon yang tidak baik hanya akan menghasilkan buah yang tidak baik. Orang berdosa hanya dapat melakukan perbuatan dosa. Dalam Yohanes 15, Yesus memberikan perumpamaan tentang pokok anggur. Perumpamaan ini mengajarkan bahwa ketika manusia ada didalam Yesus, maka manusia akan dapat melakukan perbuatan yang dikenan oleh Tuhan. Manusia diluar Yesus tidak hanya tidak akan berbuah bahkan akan dibinasakan. Oleh karena itu, manusia berdosa tidak akan dapat menghasilkan perbuatan yang baik.

Rasul Paulus juga memberikan pernyataan yang sama. 1 Korintus 12:3 menyatakan bahwa tanpa Roh Kudus manusia akan menghujat Yesus. Roma 8:1-

\footnotetext{
${ }^{16}$ Four Menius Zendrato et al., "Studi Tentang Dosa Menurut Yehezkiel 18 : 20," Eresi: Jurnal Teologi dan Pendidikan Kristen 1, no. 1 (2020): 29.

17 Setiawan, "Dampak Injil Bagi Transformasi Spiritual Dan Sosial," 87.
}

8 mengajarkan bahwa manusia yang masih dalam dosa tidak mungkin dikenan Allah.

Rasul Paulus menjelaskan lebih lanjut bahwa manusia berdosa juga tidak dapat memahami kebaikan. 2 Korintus 3:12-18 mencatat bahwa hati manusia berdosa tertutup oleh suatu selubung. Akibatnya orang-orang berdosa tidak dapat mengerti kebenaran.

Dosa tidak hanya membuat manusia tidak dapat memahami kebaikan. Manusia bahkan menolak kebaikan dan mengingini kejahatan. ${ }^{18}$ Yohanes 1:11 memberikan narasi bahwa manusia berdosa menolak Yesus yang datang menjadi juru selamat manusia. Yesus yang adalah Tuhan datang kepada manusia ciptaan-Nya, tetapi manusia menolak. Yohanes 8:43 mencatat bahwa orang Yahudi tidak menerima ajaran Yesus karena mereka berasal dari Iblis yang berdosa. Ajaran Yesus berasal dari Tuhan. Orang Yahudi dan Yesus bertentangan karena mereka bersumber dari sumber yang berbeda. Oleh karena itu, orang berdosa akan menolak kebaikan yang dari Tuhan. Fakta ini menunjukkan kerusakan manusia akibat dosa.

Penjelasan tentang bagaimana manusia yang sempurna dapat berubah menjadi buruk. Oleh karena itu, tidak aneh bila ada orang Atheis yang yang mengambil kesimpulan bahwa manusia sama dengan binatang. Dosa merupakan hal yang serius karena membawa kerusakan kepada manusia. Namun kesempurnaan manusia merupakan fakta yang tidak dapat dielakkan. Kesempurnaan inipun masih memberikan dampak pada

\footnotetext{
18 Maria Widiastuti, "KONSEP KESELAMATAN DALAM AJARAN CALVINISME," Jurnal Pionir LPPM Universitas Asahan 5, no. 4 (2019): 292-293.
} 
kehidupan manusia saat ini. Dampak tersebut dapat terlihat dari bagaimana Allah memandang manusia.

\section{Manusia di mata Allah}

Kitab Yesaya 43: 4 menyatakan bahwa bahwa manusia ciptaan Allah itu berharga dan mulia di hadapan-Nya. Selajutnya Yesaya 43: 7 menjelaskan tentang tujuan Allah membuat manusia yaitu untuk kemuliaaan-Nya. Artinya bahwa sesuatu mampu menyatakan kemuliaan Allah apabila sesuatu itu adalah istimewa. Firman Allah juga mengatakan bahwa Allah begitu mengasihi dunia yang berdosa ini. Injil Yohanes 3:16 merekam Bukti kasih Allah kepada dunia. Kasih Allah ini terbukti dengan Yesus, sang Anak Allah, turun ke dunia agar manusia memperoleh jalan keselamatan dan tidak binasa karena dosa. Manusia yang sudah jatuh dalam dosa itu kemudian ditebus dengan harga yang mahal. Surat 1 Petrus 1:18-19 menyatakan bahwa manusia yang jahat karena dosa ditebus oleh darah Yesus yang tidak bernoda dan tidak bercacat.

Allah merindukan agar manusia berdosa dan yang sudah mengalami kerusakkan keserupaan dengan Allah itu mendapatkan pemulihan. Allah sendiri kemudian segera mengambil tindakan penyelamatan. Tindakan penyelamatan manusia ini tercatat dalam Kejadian 3:15 yang dikenal dengan protoevangelium. Protoevangelium mengambarkan bahwa Allah akan menebus dosa manusia melalui seorang penebus dari keturunan manusia dan sang penebusan manusia ini akan menderita karenanya. Akhirnya Allah menjelma menjadi manusia (Yoh 1:14) dengan misi ganda. Pertama, melakukan penebusan manusia dari dosa dengan cara menggantikan hukuman yang seharusnya dikenakan kepada manusia berdosa. Petrus menyaksikan bahwa Yesus telah menggantikan hukuman yang seharusnya ditanggung manusia melalui karya penebusan di kayu salib. dengan karya penebusan Yesus manusia menjadi terbebas dari dosa dan dapat melakukan kehendak Allah lagi (I Petrus 2:24).

Kedua, ketika menjelma menjadi manusia Yesus memberi teladan dan contoh bagaimana seharusnya manusia bisa kembali hidup menurut gambar Allah. Paulus mengatakan bahwa Yesus adalah perwujudan dari Allah yang tidak terlihat yang akan membawa manusia kepada kebenaran dan kemuliaan seperti saat manusia diciptakan (Kolose 1:15, Roma 8:28-30). Jadi Allah menghendaki manusia yang sudah ditebus berproses untuk dipulihkan menjadi sempurna seperti Kristus yang adalah gambar Allah (Matius 5:48, Efesus 4:13).

Pemaparan Firman Allah tersebut menunjukkan bahwa sesungguhnya manusia adalah makhluk ciptaan Tuhan yang istimewa, ciptaan yang mulia, dan ciptaan yang unik dan sempurna.

Kembali ke permasalahan perbandingan indra manusia dengan indra binatang yang dijadikan dasar penilaian kritikus Alkitab bahwa manusia bukan ciptaan Tuhan yang sempurna. Pertama, kritikus sudah salah dalam memahami Alkitab karena kesempurnaan manusia itu terkait dengan kepribadian manusia yang segambar dan serupa dengan Allah. Sempurna bukan dalam arti memiliki segala perlengkapan hidup melebihi semua kemampuan yang dimiliki ciptaan lain seperti beruang, anjing pelacak dan lainnya sebagaimana dipaparam di bagian awal. 
Binatang sekalipun memiliki kemampuankemampuan tertentu yang berbeda bahkan melebihi kemampuan manusia namun binatang tidak dibuat serupa dan segambar dengan Allah.

Kedua, hanya dengan membandingkan indra manusia yang kalah dibandingkan indra binatang tidak bisa untuk menunjukan bahwa manusia bukanlah makhluk ciptaan Tuhan yang mulia, sekaligus kondisi tersebut memberikan pembenaran bahwa beberapa binatang adalah makhluk yang lebih baik dari pada manusia. Sangat tidak sepadan membandingkan binatang dengan manusia, meskipun beberapa binatang tersebut memiliki kelebihan dalam hal indra dibanding indra manusia. Sesungguhnya yang dinyatakatan sebegai kelebihan oleh kaum Ateis hanyalah perlengkapan yang Allah berikan kepada binatang-binatang tersebut untuk menjamin kelangsungan hidup dan bertahan dari ancaman keamanan bagi dirinya dan konteks hidup di antara sesame binatang yang lain.

Mengenai perbuatan kejam manusia yang bahkan dikatakan kaum Ateis tidak dilakukan oleh binatang, dapat dijelaskan dari kitab Kejadian pasal 3. Berdasarkan Kejadian 3, nyata bahwa manusia memilih melanggar peritah Allah dan mengabaikan kebaikan Allah yang memberi kebebasan menikmati segala buah pohon dalam taman Eden. Padahal manusia itu diciptakan sebagai makhluk moral, berbeda dengan binatang, yang mestinya lebih menghargai kebaikan Allah itu. Memang pengetahuan moral itu membutuhkan pendidikan. Ada dua cara untuk belajar, yaitu: a). seperti Adam dan Hawa, mencoba sendiri; b). bertanya pada orang yang tahu. Pelajaran moral pertama bagi Adam dan Hawa ialah suatu larangan yang kecil saja. Sepatutnya disimpulkan, bahwa apabila mereka lulus ujian pertama ini, maka ujian-ujian berikutnya akan semakin kompleks. Mereka diperhadapkan pada situasi yang membingungkan. Seharusnya mereka bersabar sampai dapat menanyakan masalahnya kepada Tuhan, tetapi mereka kurang sabar. Mereka bersedia mendengarkan penjelasan sumber lain sehingga tertipu dan langsung melanggar perintah Allah dengan memakan buah pohon pengetahuan baik dan jahat. Dengan demikian, manusia memberontak ketetapan Allah. Keberdosaan mereka mengakibatkan salah satunya yaitu mereka tidak mau bertanggung jawab. ${ }^{19}$ Ketika adam ditegur Allah maka adam menyalahkan Hawa. Hawa juga tidak mau disalahkan maka ia menyalahkan ular (Kejadian 3: 11-13). Keberdosaan juga mengakibatkan tindakan kejahatan tanpa merasa bersalah. Ketika Kain membunuh Habil adiknya dan ditegur Allah jawabnya: "aku tidak tahu, apakah aku penjaga adikku?" (kejadian 4:8). Ketika manusia jatuh dosa dan hidupnya dikuasai dosa, maka orang yang melakukan perbuatan kejam melebihi binatang, melakukan kebiadaban yang bahkan tidak dilakukan oleh binatang.

Surat Roma 1:18-32 memaparkan bahwa akibat dosa manusia melupakan Allah, tidak lagi memuliakan Allah, pikiran manusia menjadi kacau dan hatinya redup dan tidak berfungsi sebagaimana mestinya. Pikirannya terkutuk dan melakukan berbagai hal yang dilarang dan dikutuk oleh Allah. Apabila manusia sadar akan semua ini dan mau berbalik

\footnotetext{
${ }^{19}$ Heath, Tafsir Kitab Kejadian, 54-55.
} 
untuk menerima Yesus sebagai Tuhan dan Juruselamatnya secara pribadi, maka akan mengalami pengampunan dosa dan pemulihan sehingga mampu hidup kembali secara benar, baik dan bertanggungjawab sebagaimana rancanan Allah semula.

\section{KESIMPULAN}

Kesimpulan penelitian ini yaitu berdasarkan penjelasan Alkitab manusia merupakan ciptaan Tuhan yang istimewa, mulia dan sempurna dan diciptakan dengan tujuan yang baik. Manusia berbeda dengan binatang. Beberapa indra binatang yang lebih baik daripada manusia tidak menunjukan bahwa manusia memiliki kualitas dibawah atau sama dengan binatang. Juga perbuatan-perbuatan jahat manusia yang melebihi bahkan tidak dilakukan oleh binatang sekalipun, bukan berarti manusia lebih buruk dari binatang. Manusia melakukan kejahatan lebih jahat dari binatang perbuatan karena telah jatuh dalam dosa yang mengakibatkan mengalami kerusakan dirinya sebagai imago dei. Untuk itu manusia harus bertobat dari dosa-dosanya agar hidupnya diperbaharui di dalam Tuhan Yesus sebagai Penciptanya untuk kemudian diperbaharui menjadi serupa dengan Kristus yang adalah gambar Allah dan menampilkan pola hidup sesuai rancangan Allah sejak semula yang selalu baik adanya.

\section{REFERENSI}

Akil, Husein Avicenna. "Sepuluh Kali Lebih Sensitif Ketimbang Manusia." Lembaga Ilmu Pengetahuan Indonesia. Last modified 2010.

Accessed March 25, 2021. http://lipi.go.id/berita/sepuluh-kalilebih-sensitifketimbang- manusia/5648.

Berkhof, Louis. Teologi Sistematika 2. Jakarta: Lembaga Reformed Injili Indonesia, 1994.

Diputra, Rizka. "Lima Hewan Dengan Indera Penciuman Terbaik Di Dunia." Okezone.Com. Last modified 2016. Accessed March 25, 2021. https://techno.okezone.com/read/2016 /03/24/56/1344743/lima-hewandengan-indera-penciuman-terbaik-didunia.

Enns, Paul. The Moody Handbook of Theology. Chicago: Moody Press, 1989.

Heath, W. Stanley. Tafsir Kitab Kejadian. Yogyakarta: Yayasan Andi, 1998.

Kawangmani, Soleman, and Irawan Budi Lukmono. "Efektivitas Pembelajaran Agama Kristen Melalui Mata Kuliah Pendidikan Agama Kristen Di Perguruan Tinggi Terhadap Pemahaman Mahasiswa Kristen Tentang Gambar Diri.” Jurnal Gamaliel : Teologi Praktika 2, no. 1 (2020): 1-10.

Lumintang, Stevri Indra Danik Astuti Lumintang. Theologia Penelitian Dan Penelitian Theologis ScienceAscience Serta Metodologinya. Jakarta: Geneva Insani Indonesia, 2016.

Moleong, J. Lexy. Metode Penelitian Kualitatif. Bandung: PN Remaja Rosdakarya, 1997.

Purwantara, Iswara Rintis. Prapenginjilan, Menyingkirkan Kendala-Kendala Intelektual Dalam Penginjilan. Yogyakarta: Penerbit Andi, 2012.

Ridenour, Fritz. Dapatkah Alkitab Dipercaya? Jakarta: PT. BPK Gunung Mulia, 1993.

Setiawan, David Eko. "Dampak Injil Bagi Transformasi Spiritual Dan Sosial." BIA : Jurnal Teologi dan Pendidikan Kristen Kontekstual 2, no. 1 (2019): 83-93.

Widiastuti, Maria. "KONSEP 
KESELAMATAN DALAM

AJARAN CALVINISME." Jurnal

Pionir LPPM Universitas Asahan 5, no. 4 (2019): 288-296.

Yudha, and Bayu D. Wicaksono. "7

Hewan Dengan Pendengaran Terbaik

Di Dunia, Kelelawar Bukan

Juaranya!" IDN Times. Last modified

2019. Accessed March 25, 2021.

https://www.idntimes.com/science/dis covery/viktor-yudha/hewan-denganpendengaran-terbaik/7.

Zendrato, Four Menius, Sekolah Tinggi, Teologi Injili, and Arastamar Nias.

"Studi Tentang Dosa Menurut Yehezkiel 18 : 20.” Eresi: Jurnal

Teologi dan Pendidikan Kristen 1, no. 1 (2020): 23-33.

"Ciptaan Yang Luar Biasa." Rehobot

Ministry. Last modified 2018.

Accessed March 26, 2021.

https://www.rehobot.org/beranda_ren ungan/ciptaan-yang-luar-biasa/.

"Mengapa Pendengaran Anjing Lebih Peka Dibanding Manusia?" DW.Com. Last modified 2018. Accessed March 25, 2021.

https://www.dw.com/id/mengapapendengaran-anjing-lebih-pekadibanding-manusia/av45102248\#: :text=Iptek-,Mengapa Pendengaran Anjing Lebih Peka Dibanding Manusia\%3F, dan jadi tidak bisa tenang. 